\title{
Tourist settlements in the Comunidad Valenciana coast: A Typological Map
}

\author{
Marilda Azulay Tapiero, Vicente Mas Llorens \\ Departamento de Proyectos Arquitectónicos. Universitat Politècnica de Valencia, Valencia, Spain \\ E-mail: mazula@pra.upv.esvmas@pra.upv.es
}

\begin{abstract}
The system of tourist settlements on the Mediterranean coast presents a great complexity, as well as its geographical, landscape, morphological, urban and architectural conditions like for the varied way of relating to it the social and economic groups involved. The purpose of the communication is to expose the research about the need and the possibility of actions providing tourist settlements with urban and territorial cohesion, and enabling new proposals where what is decisive is not only acting on the parties but, globally, on the conditions that defines the scenes of action. In order to deal with the complexity of the tourist development on the Valencian Mediterranean coast, we proposed, as a first step, the identification of settlement types where, contrary to the buildings type, it will be necessary to apply mechanisms that take into account there are structures in the process of evolution. As Giorgio Grassi (1973) already said, a classification is not a type but allows an approximation to it. This has allowed the development of a "Typological Map of Tourist Settlements in the Comunidad Valenciana" where situate case studies while reading the territory as a whole and each settlement in relation to others settlements. A map to add data, based on the definition of parameters related to structure, urban form and architecture, but also to the relationship with the coastal physical environment, and selected for their capacity to provide data for the research purposes.
\end{abstract}

Keywords: Typological Map, Tourist settlement, Valencian Mediterranean coast, Complex System.

\section{Introduction}

The touristic settlements system on the coast shows profound complexity both because of geographic, landscape and urban conditions and also because of the scheme of elements to be considered. We refer to "complexity", in accordance with Edgar Morin (2004), as a network of heterogeneous, inseparably connected constituents. Likewise, a complex system is the one in which it is possible to find a network of events, actions, interactions, retroactions, decisions and chances which create our phenomenal world (Morin, 2004). When addressing the concept of complex system, it is necessary to take into account the set of elements (or parts) interacting with each other and with the surrounding environment. In this sense, its intelligibility cannot be found only within the system but also in its relation with the environment; this relation is not a mere dependency but has to be seen as a constitutive element of the system.

Complexity is the starting point from which it is possible to establish strategies for sustainable regeneration of touristic urbanisation in order to improve physical and environmental conditions of the Mediterranean coastal strip; moreover, complexity encourages a vision of the territory as the simultaneous expression of unity and diversity, as a system of differences, according to Mar Loren (2014). This is the main goal of a typology map of Comunidad Valenciana touristic settlements that, as a tool for analysis, allows analysing the territory as a whole and each settlement in relation with its closest environment. 
On the other hand, this strategy allows us to imagine action scenarios according to information, indeterminacy and random elements participating or even disrupting the course of the action. To this effect, the strategy has to fight against randomness through a comprehensive search for information, combining different knowledge sources.

In this work, the typology map of touristic settlements on the Comunidad Valenciana coast has been analysed on the basis of parameters chosen considering the development of "Estrategias para la regeneración sostenible de asentamientos turísticos en la costa mediterránea" ["Strategies for the sustainable regeneration of touristic settlements in the Mediterranean coast"]..$^{1}$ This is a research project which originated from the hypothesis that it is possible to find effective solutions to the touristic settlements' regeneration that, as a factor for economic, social and territorial development, do not imply territorial, structural, architectural or landscape disruption but, the other way round, that could become a driving force for territorial regeneration implying its recovery, restoration and reuse. The research project, whose results are collected in the publication Orilla marítima. Territorio litoral (2015) [Seashore, Littoral Territory], does not propose specific projects but looks into the need and possibility of actions and projects, and their recommended orientation, underlining the necessary effort in order to construct realities which are more and more multidimensional, transnational and transversal. (Figure 1)

\section{Touristic settlements on the littoral}

For the sake of clarity, it is necessary to specify the nature of the subject of study - the touristic settlement -, as the city is also the urban way of living, a network of relations between constructions and behaviours. Thus, at another stage the identification and participation of the dweller will be necessary, as a co-creator/author and active participator-

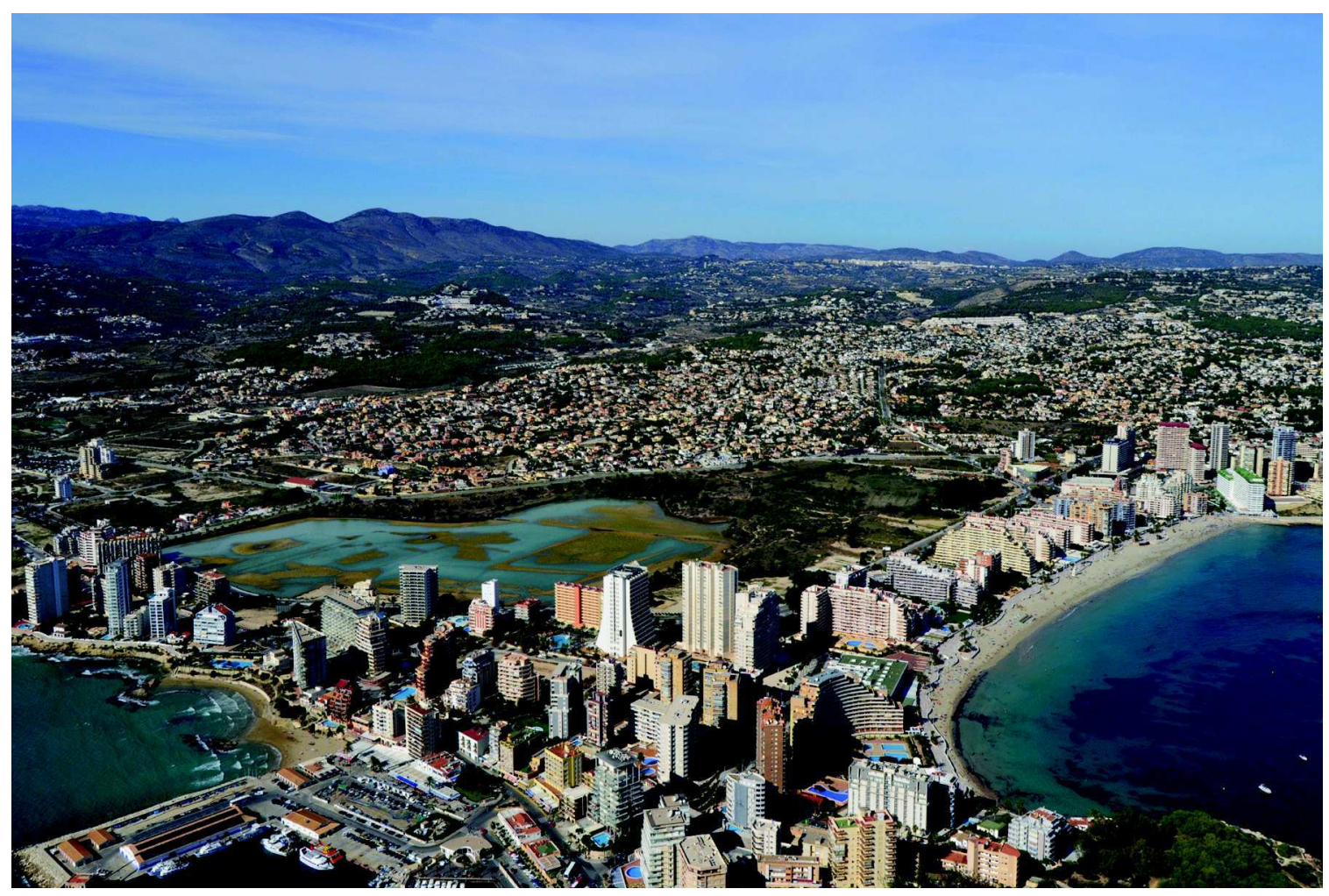

Figure 1.

Calpe, Marina Alta. Alicante.Views from Peñón de Ifach. https://commons.wikimedia.org/wiki/File:Vistes_des_del_penyal_d\%27Ifac,_Calp,_Marina_Alta. JPG accessed 20 May 2017. 


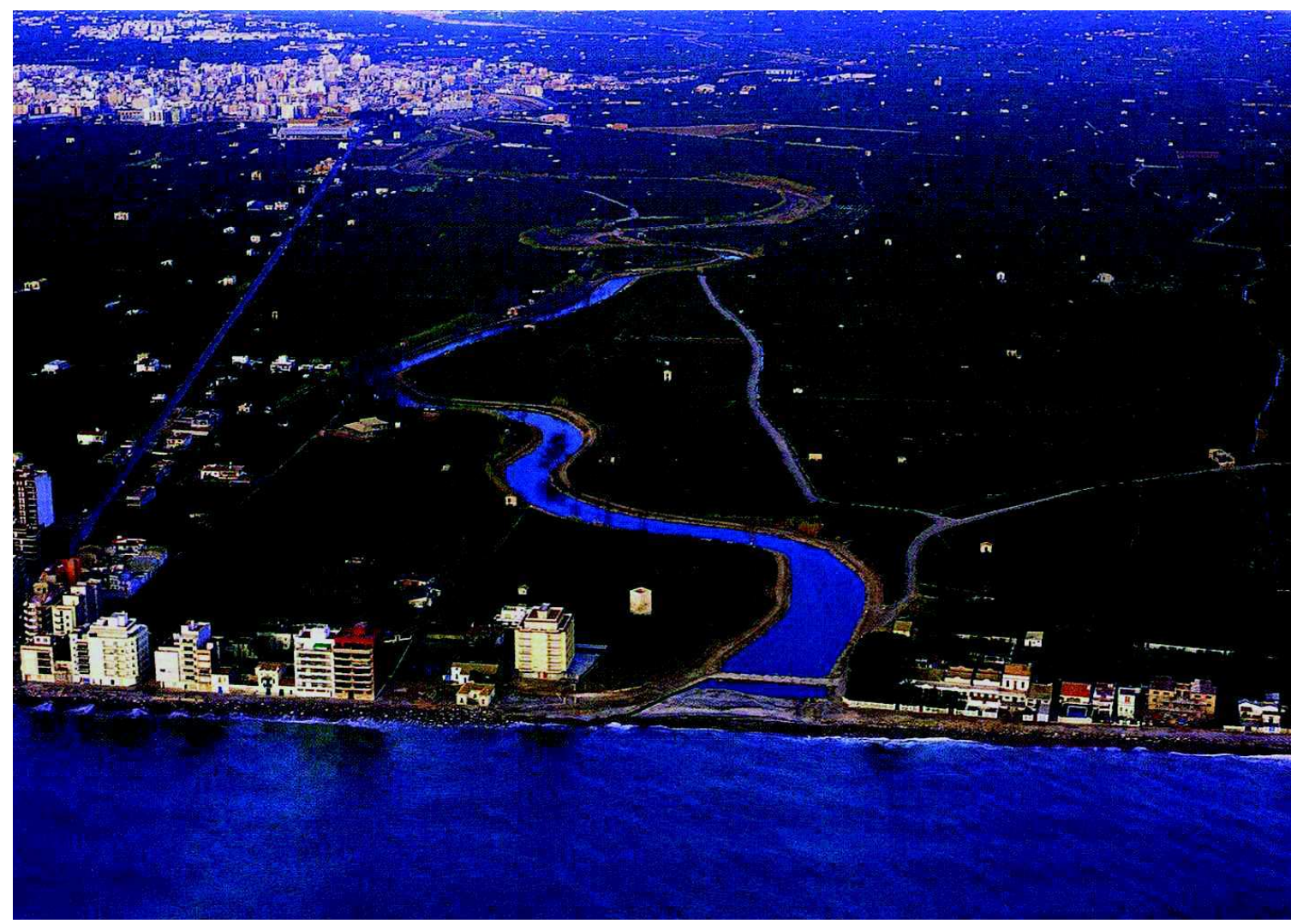

Figure 2.

The Ana river north of Grau de Burriana, Plana de Castellón. In Salvador Peiró (photo) (1989). Guía de la Naturaleza de la Comunidad Valenciana (Levante, Valencia) 501.

voluntarily or involuntarily - in building the city and in interpreting the dialogue between the territory and its dwellers, its scenarios and time frames. All this, for the purpose of this work, in a specific geographic area: the coast, a constantly changing and evolving system, with a high ecological value and a considerable biodiversity, a space of transition between terrestrial and marine systems and in which there are intense interactions and exchange processes.

On this littoral, it is possible to find a settlement method developed over the last decades of the 20th Century, which has been transforming large coastal strip areas with a high urban growth from juxtaposed constructions to a built-up continuum. Such interventions entailed functional and landscape territorial changes. It has been an urbanisation of holiday villages and seasonal supply, firstly based on relations between urban historic areas (characterised by urban functions) and first coastal settlements (foundation of economic, agricultural and fishing activity mainly), and later based on a series of accommodation, catering and services buildings that started taking up and over territorial areas unspoilt until then. The evolution of these settlements was firstly subject to factors such as hydrography, communication ways or economic activities on the coast but also residential areas. All factors contributed to the creation of a large mesh with an increasing dispersion towards the interior, facilitated by motorisation and improvements in the communication structures, with the consequent increase in mobility flows, complexity in the use of soil and settlement types. A territory in which, as Mar Loren (2014:19) said in reference to Costa del Sol, "dwellers from different zones run into each other but seldom look at each other, they use the same infrastructures but they rarely go to the same place".

Accordingly, getting to know the touristic settlement means both to consider its characteristics, tourist reception device and 
the consequences of its implementation on the territory, and also its population, social interaction, positioning strategies and reasons and consequences both on the welcoming population and on its surrounding environment population. These are dynamic aspects of this issue which, in the Comunidad Valenciana, are even more visible concerning due to the big presence of second home settlements for native population alongside with the strictly touristic activity, sharing resources and territorial structures. However, as Alfonso Fernández y Arsenio Villar (2011:598) stated, "the extraordinary proliferation of second homes, with the consequent pressure on resources and structures (beaches, soil, water, landscape, communication and supplying infrastructures, water treatment, etc.), ended up damaging the tourist experience in those areas"; so that this second homes proliferation was pointed out, even by travel agents, as the main problem of the touristic model on the Andalucia and Spanish coast. (Figure 2)

Dealing with tourist reception device and starting from the diversity of ways that tourism can take on, we consider that the touristic settlement is the expression on the territory of the way of living created for touristic purposes and as a consequence of specific occupations, conformations and transformation of the space, social and socioeconomic relations etc. - both during touristic influx and also when this influx decreases or stops, both on the welcoming population and on its surrounding population. We have to consider, as Amos Rapoport (1977) pointed out, that contrarily to the idea of landscape and climate determinism, geographic location is not a construction imperative. Or, according to Almeida, Mora i dos Reis (2010:910), "architectural forms change in areas where geography hasn't changed, as for example on the Mediterranean coast".

Throughout this research, each settlement has been identified from the point of view of toponymy and of its identity, administrative or geomorphological character, defining throughout the Comunidad Valenciana littoral a total number of 205 touristic settlements in 60 coastal municipalities. Among those, 49 in Castellón province in 16 municipalities, 58 in Valencia province in 24 municipalities, and
98 in Alicante province in 20 municipalities. However, regardless of the number of settlements and in order to better understand the dominant implementation structure in the Comunidad Valenciana it is also necessary to be aware of the coastal length considered: of the $418.354 \mathrm{~lm}$ taken into account, 272.154 $\operatorname{lm}(65 \%)$ present a consolidated urban front. (Figure 3)

\section{Classification}

From this point of view, the understanding of the situation of touristic settlements on the Mediterranean coast cannot be based only on the accumulation of specific data on each settlement. But also social circumstances, economic conditions, physical support of the territory and population habits show sufficient common features in order to suppose that there is a limited number of settlement types.

In the architectural field, the existence of these basic structures is considered settled to such extent that Aldo Rossi (1979:69) stated that the type is "the very idea of architecture". But the interesting matter for our purpose is not the building types but the implementation of settlement types, and in order to understand them it is necessary to use classifying methods which take into account that these are not complete accomplished realities but structures in a process of evolution.

As Giorgio Grassi (1973) said, a classification is not a type but allows us an approximation. In this sense, a settlement type as the one we suggest has to be seen basically as a tool that helps us obtaining a useful classification for our research goals. Every classification is based on a criterion or on a coherent combination of them, and it is not possible to say that some criteria are better than others unless this is based on if they are more or less capable to give us useful data for the research goals. Thus, one of the first works accomplished in the research Touristic settlements on the Comunidad Valenciana coast in order to make it effective in the creation of an intervention strategy, was the creation of a Typology Map. For this, it has been necessary to establish classification criteria, to rank them according 


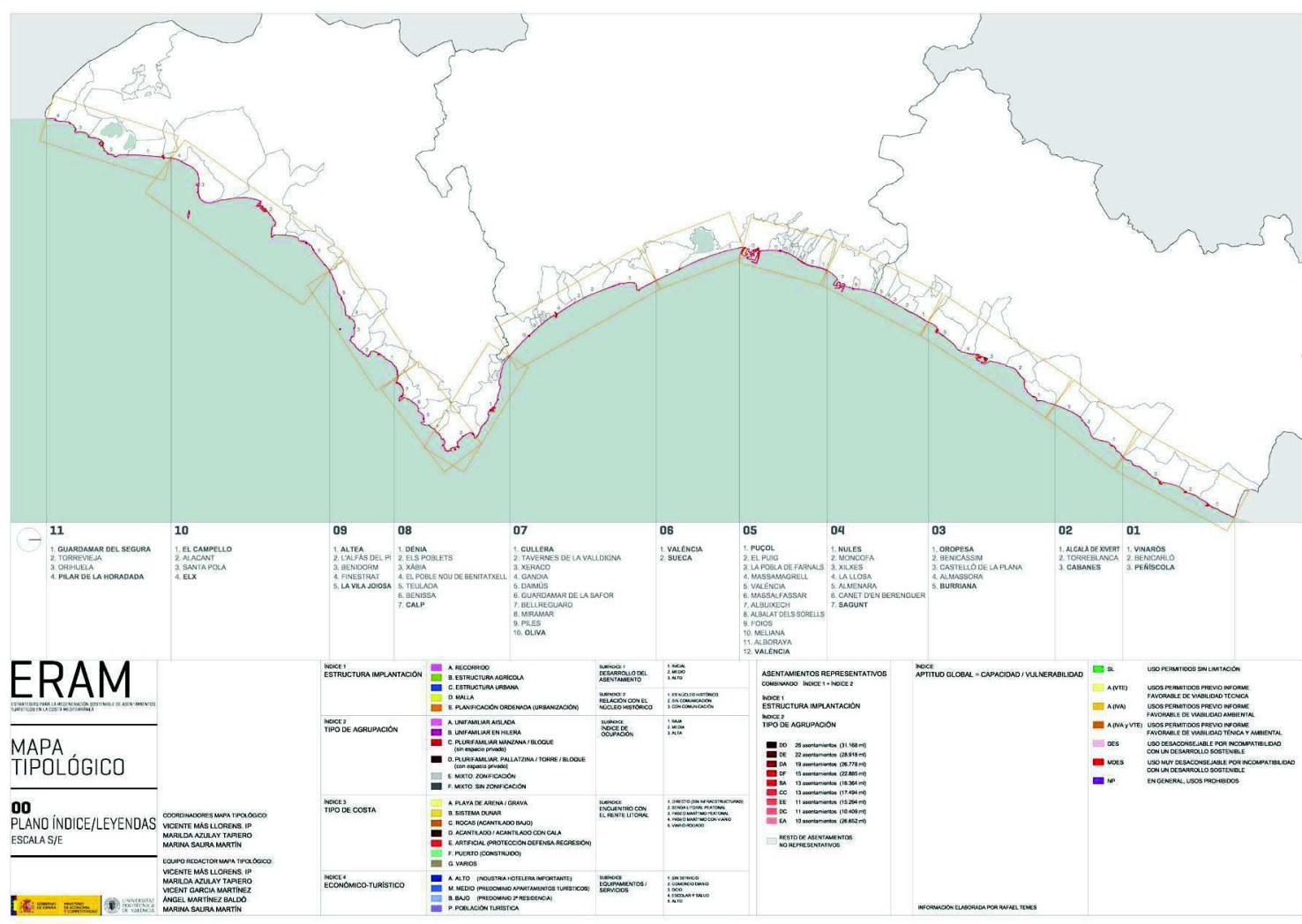

Figure 3.

Typological Map. Sectors and Legend.

to their effectiveness and decide the degree of interdependence among them.

\section{Typology map of the Comunidad Valenciana touristic settlements.}

As Leslie Martin (1975) explained, cities are built from quite a simple range of situations: a network of streets, the plots created from this network and the buildings' distribution on them. However, the understanding of their relations is essential in order to rethink the cities structure.

The first approach has been the establishment of four indices grouping interdependent criteria while also establishing typifying sub-indices, for the need to consider different development degrees of the settlements.

1. Implementation structure, differentiating groups around a road axis or according to the consolidation of the pre-existent agricultural structure in systems based on an orderly planning aiming at touristic or second home exploitation, cities intentionally created by planners as Christopher Alexander (1968) defined them. We added the mesh on the way, a kind of board establishing the rules of the game, according to Martin (1975).

Sub-indices define the degree of development and point out the degree of connection between the settlement and urban areas and their functions. The degree of development of the settlement is an indicator of a situation in time, while high development levels shall determine possible actions.

2. The second index is the predominant grouping type in different structures.

It is about determining what building types there are within the settlement and their distribution in it; all this, differentiating between the field of one group (isolated singlefamily home, grouped single-family homes, multi-family dwellings in blocks or towers etc.) and of other groups where it is not possible to establish a predominant type because there are various types at the same time, regardless of motivation or evolution in time. Anyways, 


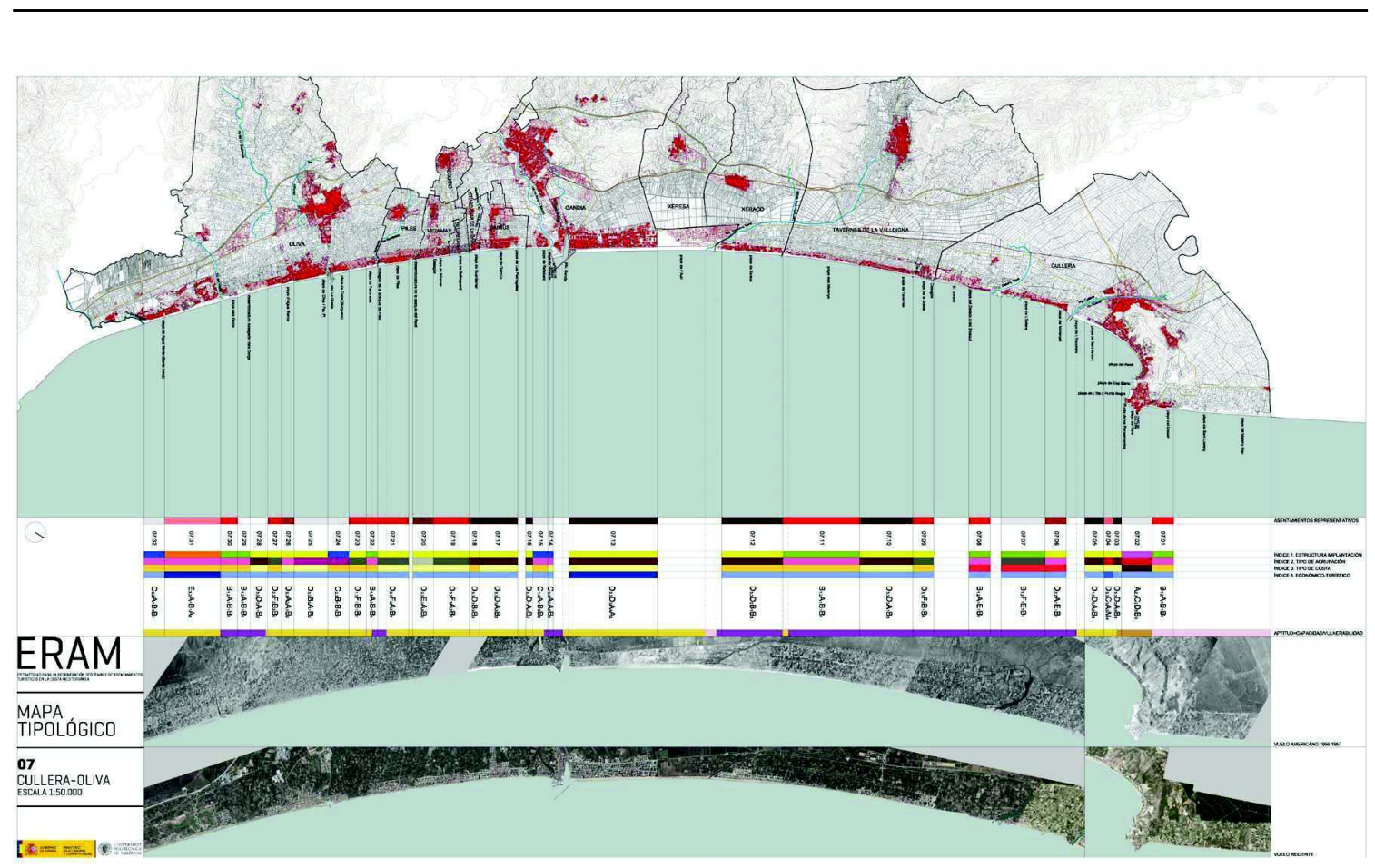

Figure 4.

Typological Map. Sector 07. Cullera-Oliva. Valencia.

the important aspect for this study is not the architectural type but its consequences on the urban space; for this reason the sub-indices point out the concentration and occupancy degree or, in other words, the presence of available spaces. All this together with the urbanising process development degree on the territory allows us to define a qualitative and quantitative evaluation of functional and formal features of settlements and consequently suggests scenarios for the implementation of settlement regeneration strategies.

3. The aim is to analyse the influence of the coastal line, with a diverse morphology on the Mediterranean coast, both from the point of view of natural elements and of actions, especially those aiming at protecting the coast. A specific aspect is port spaces and beaches created by port structures, their position regarding the city and especially their dimension.

The sub-index defining the way in which those are connected to the coastal line is relevant: seafront promenades, shore paths, traffic streets etc.; the presence or not of transition areas where to find or not different structures. This connection, always present, will show the level of accessibility and connection between the settlement and the coastal line.

4. It is clearly hard to analyse the unregulated accommodation supply, and for this reason the economic-touristic parameter classifies settlements according to touristic industry or second home. The sub-index shows, in this case, the different levels of services in the settlements and its analysis can provide us with new ideas about mobility within the territory.

\section{Methodology}

The indices listed generated a typology map of touristic settlements on the Comunidad Valenciana coast from which it is important to highlight the "settlement register", defined by the four indices in the current situation, characterised by the corresponding sub-indices.

The map, with a 1:50.000 scale, has been developed from the cartographic base of municipalities with access to the sea and, each one of those, with 500 metres of littoral front, in an attempt to create a unitary base on which it will be possible to gather such a diverse information both in terms of variety of sources and in terms of formats and media where it is available. 
Toponymy was established based on the documents provided by Instituto Cartográfico, from the contents on the portal Terrasit of Generalitat Valenciana and the "Beaches Guide" of the Ministry of Agriculture, Food and Environment, as well as from fieldworks and various municipalities' websites. Finally, among the different grassroots works, the chosen criterion has been the one from the Plan de Acción Territorial del Litoral de la Comunidad Valenciana (2006) ${ }^{2}$ [Territorial Action Plan of the Comunidad Valenciana littoral], which divides the Comunidad Valenciana coast in eleven units. As stated in its report, the areas subject to different regulations, even though they all have in common a strong urban pressure on the coastal line with the consequent massive occupation of the territory. .

The map describes each settlement accrding to four points of view; each one interpreting an index, with an added fifth one defining how suitable the territory is for urbanisation. (Figure 4)

1. In reference to Index 1 -settlement structure-, the results refer to the number of settlements and to percentages according to the total number of settlements. $46,34 \%$ of the total are built with a mesh structure, different in dimensions and shapes; on the other hand, an agricultural structure is present in only $7,80 \%$ of the settlements. Anyway, the development rate is high as well as urban functions.

Another key aspect is the analysis of this index according to sectors and provinces, referring both to the number of settlements and of the length of the coast affected by the settlement structure. In this sense, the mesh structure, predominant in the Comunidad Valenciana as a whole, is predominant in length as well even though it has a lower presence in the Alicante province $(37,76 \%)$ - where there are $63,63 \%$ out of the 44 settlements with planned structure- than in Valencia $(56,90 \%)$ or Castellón province $(53,06 \%)$.

Alicante as well shows a high degree of development of the settlement, and just 5,26\% of total is on an initial level.

2. In reference to Index 2 - grouping type - we analysed the settlements characterised by single-family homes (detached or terraced), by multi-family dwellings (with or without free private space) and where the different types can be found: in almost a third of the total of settlements $(31,70 \%, 35,12 \%$ y $33,17 \%)$ there is each one of the groups. Neither considering the province of location can we find a predominant grouping type, except for maybe multi-family dwelling in Alicante, in Valencia mixed types in Valencia and single-family homes in Castellón.

On the other hand, in $54,15 \%$ of settlements, constructions occupy between 25 and $50 \%$ of the soil.

3. The analysis of geomorphological features of the coast as the third index - coastal typecharacterised by a sub-index referring to the way in which the different types are connected, allows us to add to this work the component of urban coastal landscape, considering the coastal length as a significant value.

The index "sand/gravel beach" has the highest number of settlements in each one of the three provinces as well as the largest coastal length. Of these settlements, $67,31 \%$ have a "seafront promenade" way of connection; it is important to highlight that $23,08 \%$ of connections are "direct", with no infrastructure.

4. The fourth Index or economic-touristic parameter, as already underlined, classifies settlements according to their relation with the tourism industry or with second homes sector and it is characterised by a sub-index that analyses the presence of different services and facilities, a useful necessary aspect in order to plan actions.

In this sense, concerning the facilities of "predominance of second homes"-the highest number of settlements in the Comunidad Valenciana , 56,10\%- none of them has a high level of facilities, whereas $37,39 \%$ in the Comunidad as a whole has been classified as "without services" and 33,04\% as "daily-use businesses".

Starting from indices and typifying subindices, the "register" of each settlement and the typology map of touristic settlements took shape, settlement by settlement, sector by sector, province by province. It has been possible to add new data according to the needed information in each one of the cases. 


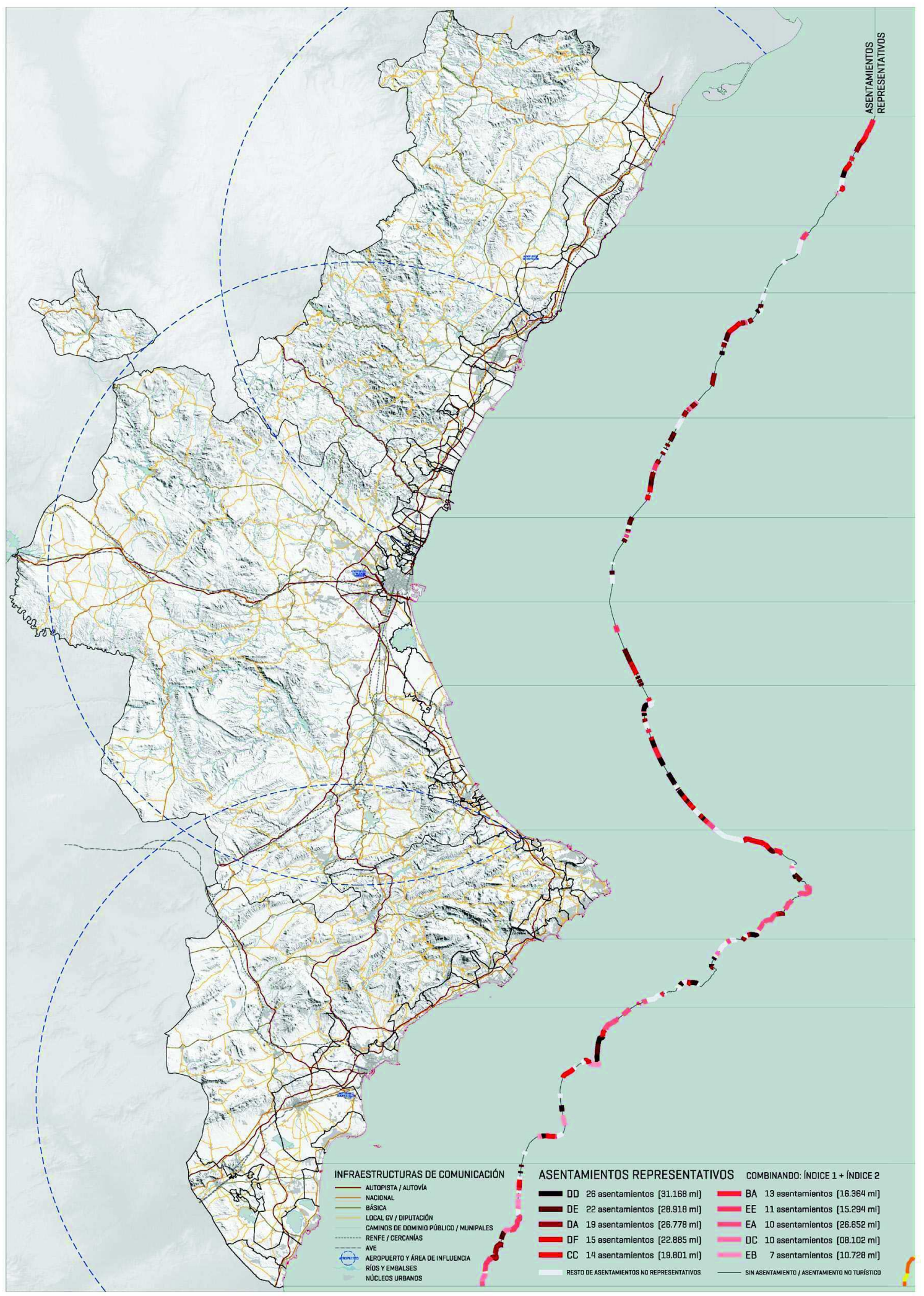

Figure 5.

Typological Map. Summary Map. 
Adding new indices and variables, and logically decreasing the number of "type" settlements, we started with 95 D-settlements until we got to 12 settlements with the type DDAB; in other words, touristic settlements on the littoral, accounting for $14.490 \mathrm{~lm}$ of coast with a mesh settlement structure on which the predominant construction is a multi-family dwelling with private space (closed to public access), with a sand or gravel beach and a predominance of second homes with a higher concentration in the sector Cullera-Oliva in the Valencia province. (Figure 6)

Anyways, the most recurrent "register" is, regardless of the second index - grouping type -, D_AB; namely, touristic settlements on the coast with a mesh structure, sand or gravel beach and predominance of second homes, accounting for more than $43.000 \mathrm{~lm}$ of urban coast.

\section{Conclusion}

More than $272 \mathrm{~km}$ of the Comunidad Valenciana littoral present a consolidated urban front ${ }^{3}$ with diverse settlement methods, mostly residential, and diverse densities. ${ }^{4}$ Such diversity, with its corresponding malfunctions, contradictions between the area's geographic features and the settlement model, which requires and tries to take over the "first line" of the littoral front, creating an important alteration on its functioning, as for the cases of building on dune ridges or obstructing river mouths, even if they lay on vulnerable or dangerous areas. (Figure 5)

Strategies for the sustainable regeneration of touristic settlements will have to enable, through concrete actions, conservation and improvement of the coastal line as a landscape valuable element, protection of coastal natural spaces and access to the coast, conjunction between design and management or approaches willing to boost engagement, always keeping in mind the leading role of tourism and its direct consequences on social, cultural and educational life but also on the economic sectors.

Likewise, strategies are based on key ideas such as a global and multidisciplinary vision

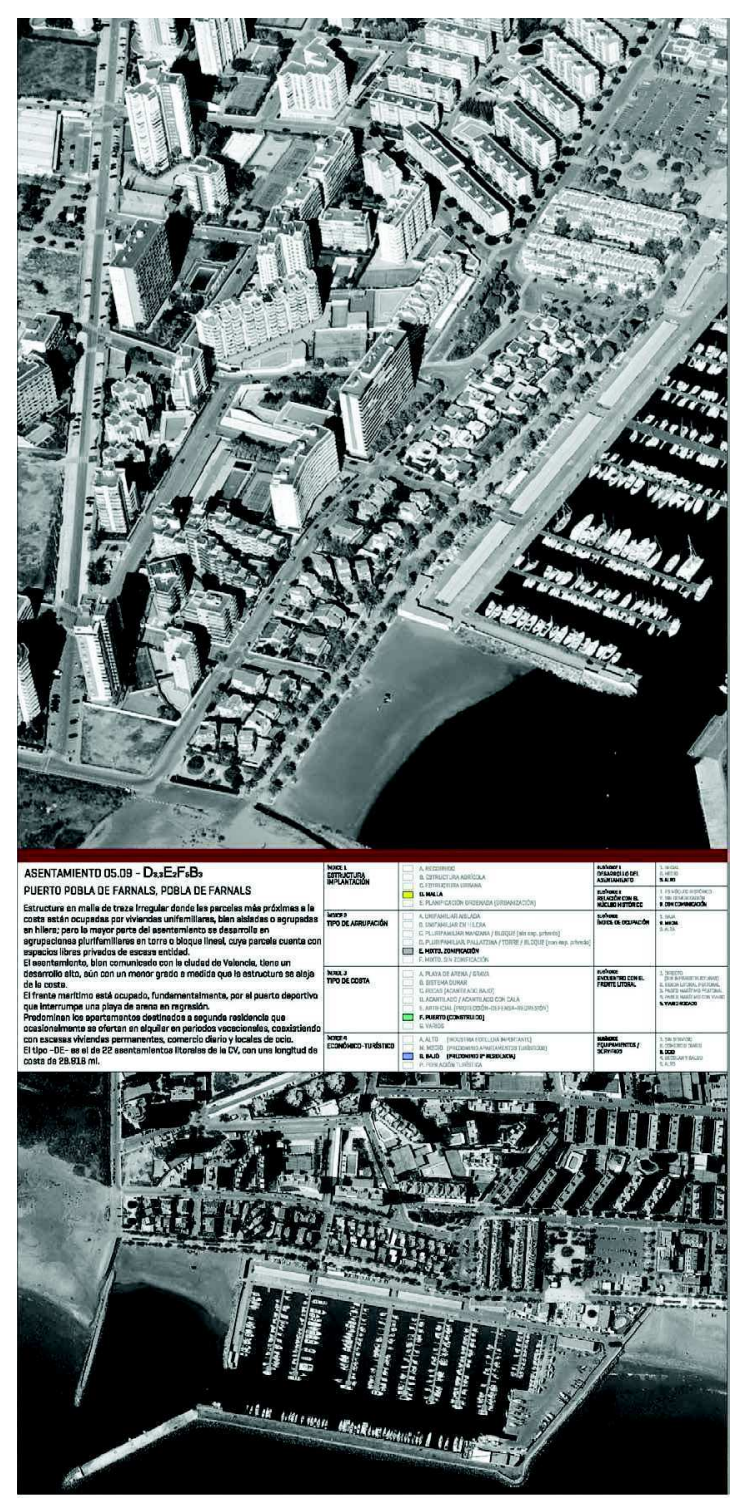

Figure 6.

Pobla de Farnals Marina. Valencia. Touristic settlement 05.09. DEFB..

of reality and need to consider, in different scenarios and scales:

a) The value of the environment, together with weather conditions, cultural, environmental and landscape assets.

b) Tourist demand in the Comunidad Valenciana that, in 2009, welcomed more than 23 million tourists. This demand is mostly domestic and people staying in second homes, being the beach the main reason for their stay, maintaining the seasonal nature of demand as a structural feature of littoral destinations, except for Benidorm.

c) Renewal of usual destinations through the 
creation of new tourism and leisure resorts on the side-line of the pre-existent urban structure, creation of emerging spaces on the pre-littoral front and inland, urban tourism boom or creation of new touristic products.

d) Territorial asymmetry both from a geographical point of view and the seasonal nature of the activity.

e) Heterogeneity of the touristic settlement types on the littoral urban front of Comunidad Valenciana in a residential building model, which requires and tries to take over the "first line" of the littoral front. This heterogeneity can mean, sometimes, extra and differentiating touristic assets.

f) Acknowledgement of the residential nature, being Comunidad Valenciana, according to data from the 2010 Documento de Base del Plan Estratégico Global del Turismo de la Comunitat Valenciana [Base Document of the Global Tourism Strategic Plan of Comunidad Valenciana], the first Comunidad Autónoma in volume of second homes (around $17 \%$ of the national total amount).

g) Given the continuity of touristic space, the touristic-territorial planning has to refer to resources, infrastructures and environmental management etc. further beyond local reality, boosting territorial cooperation. However, we have to admit that there is a lack of experience of action and supra-municipal strategies in terms of urban and touristic planning.

h) The value of participation and societylandscape interaction for a double goal: boosting sustainable and respectful behaviours towards the environment and improving information, participation and joint responsibility processes. Such involvement increases the sense of responsibility, which is the fundamental element for a sustainable development.

In particular, an action on the settlements with a mesh building structure, sand or gravel beach and predominance of second homes, enables considering the mesh as a productive grid, the sea front as a structural and shaping element of the settlement and urban life, enabling the transformation of second homes into permanent homes in specific accessible and equipped settlements on the coast. Each case will require a research and analysis of the requirements - access, communication, supply, management, health services, teachers... - in order to establish both the possibilities and the limits of such action, both for homes that have to guarantee high comfort standards and for urban areas that need the design of diverse and heterogeneous spaces through the development of specific projects for specific places.

\section{Notes}

1 Research project coordinated by Universitat Politècnica de València, department of Proyectos Arquitectónicos, and Universidad Ramon Llull, Barcelona, Enginyeria i Arquitectura La Salle, financed with funds from Plan Nacional I+D+i 2008-2011 (reference BIA2011-28297-C02-01) of the Ministry of Economy and Competitiveness.

2 2006, Plan de Acción Territorial del litoral de la Comunidad Valenciana. Generalitat Valenciana. Conselleria de Territorio y Vivienda. Dirección General de Planificación y Ordenación Territorial.

3 To that, it is necessary to add more than 30 $\mathrm{km}$ of coasts ( $7 \%$ of the total length) considered in the planning as programmed urbanised soil; the coastal line presenting any protected natural area accounts for about $134 \mathrm{~km}, 30 \%$ of the total length.

4 Leaving historic urban settlements on the littoral line and spaces for infrastructures (i.e. ports) to one side, being just a few industrial and tertiary uses, the majority of the urbanised front is intended for residential uses.

\section{References}

Christopher, A. (1968), "La ciudad no es un árbol", Christopher Alexander, Nuevas ideas sobre diseño urbano, Cuadernos summanueva visión, year 1, no. 9. 20-30.

Almeida, C., Mora, J. y Dos Reis, F. (2010) "Vivienda y Territorio", M+A. Revista Electrónica de Medioambiente UCM, no. 8, 1-17. (https://www.ucm.es/data/cont/media/ www/pag-41214/almeidamoradosreis.pdf ) accessed 7 May 2017.

Fernández, A. y Villar, A. (2011) "La distribución territorial de la actividad 
turística en Andalucía. Selección de indicadores y evolución de los mismos en la etapa reciente", Turismo y desarrollo económico. IV Jornadas de Investigación en Turismo. Sevilla, 19th-20th May 2011, 589608.

Grassi, G. (1973) La construcción lógica de la Arquitectura (La Goya Ciencia; Barcelona)

Loren, M. (2014) "La Costa del Sol como sistema de diferencias. Cartografiando el litoral" in Loren, M. (coord.) Costagrafías. El litoral turístico como sistema de diferencias. La Costa del Sol (Universidad de Sevilla, Sevilla).

Martin, L., (1975) "La trama como generador", in Martin, L., March, L. Echenique, M. (dir.) La estructura del espacio urbano (Gustavo Gili, Barcelona) 21-50.

Mas, V., Azulay, M., Saura y M. (2015) "Mapa tipológico de asentamientos turísticos de la Comunidad Valenciana", in Tuset, J.J. y Temes, R. (ed.) Orilla marítima. Territorio litoral (General Ediciones de Arquitectura, Valencia)

Morin, E. (2004) Introducción al pensamiento complejo (Gedisa, Barcelona)

Rapopport, A. (1977) Vivienda y cultura (Gustavo Gili, Barcelona)

Rossi, A. (1979) La arquitectura de la ciudad (Gustavo Gili, Barcelona)

VV.AA. (2015) Estrategias para la regeneración sostenible de asentamientos turísticos en la costa mediterránea. Resultados del proyecto de investigación ERAM, Domínguez, L. E., Ruiz, I, Serrano, B., (ed). (Instituto Valenciano de la Edificación, Valencia). 